\title{
Landscape enclaves: wine capitalism and luxury tourism in Mendoza, Argentina
}

\author{
Gabriela Pastor ${ }^{1}$ \\ Laura Torres \\ Lucio Marinsalda Pastor \\ Consejo Nacional de Investigaciones Científicas y Técnicas, Argentina \\ Universidad Nacional de Cuyo, Argentina
}

\begin{abstract}
Rural territories in the province of Mendoza, Argentina, particularly those located in the Uco Valley, have been affected by severe transformations connected to two key factors: first, the national state's (de)regulation of water use and, second, the dramatic expansion of capital into winemaking and tourism. These activities have been developed on former livestock farming areas, turning them into fresh produce farms where food production is carried out in a "natural landscape" of unquestionable beauty: the iconic scenery of Mendoza. This article deploys the concept of extractivism to analyze "enclaves of commodity landscapes" associated with high-end wine tourism. Its purpose is to show the extent to which high-end wine tourism requires a sleek and highly aestheticized enclave landscape in order to enable the commodification of singular experiences. This article suggests that: 1) The development of tourism enclaves commodifies the landscape so as to provide the sense of a unique touristic experience; 2) the development of these enclaves is underpinned by the extraction of common, collectively-constructed goods.
\end{abstract}

Keywords: Landscape; enclave; tourism; commodity; extractivism; wine

\section{Résumé}

Les territoires ruraux de la province de Mendoza, en Argentine, en particulier ceux situés dans la vallée de l'Uco, ont été touchés par de graves transformations liées à deux facteurs clés: premièrement, la (dé) réglementation par l'État national de l'utilisation de l'eau et, deuxièmement, l'augmentation du capitaux investis dans l'expansion de la vinification et du tourisme. Ces activités se sont développées sur d'anciennes zones d'élevage, les transformant en terres de produits frais où la production alimentaire se déroule dans un "paysage naturel" d'une beauté incontestable: le décor emblématique de Mendoza. Cet article déploie le concept d'extractivisme pour analyser les «enclaves de paysages marchands» associés à l'oenotourisme haut de gamme. Son objectif est de montrer à quel point l'œnotourisme haut de gamme nécessite un paysage enclavé élégant et hautement esthétisé afin de permettre la marchandisation d'expériences singulières. Cet article suggère que: 1) Le développement des enclaves touristiques marchandise le paysage de manière à donner le sentiment d'une expérience touristique unique; 2) le développement de ces enclaves est soutenu par l'extraction de biens communs construits collectivement.

Mots-clés: paysage; enclave; tourisme; marchandise; extractivisme; du vin

\footnotetext{
${ }^{1}$ Dr. Gabriela Pastor and Dr. Laura Torres, researchers at the National Scientific and Technical Research Council (CONICET) and National University of Cuyo (UNCUYO), Argentina. Emails: gpastor "at" mendoza-conicet.gob.ar, ltorres "at" mendoza-conicet.gob.ar. Lucio Marinsalda Pastor, student at National University of Cuyo (UNCUYO). Email: luciomarinsaldapastor "at" gmail.com. We are grateful to all those people in the Uco Valley who participated in the study and shared their valuable knowledge with us. We also thank the editors of the Journal of Political Ecology and the anonymous reviewers for thoughtful and helpful comments. We acknowledge support from the National Agency of Scientific and Technological Promotion through PICT 2013-1133. Translation into English by Sara García, Alison Llaver and Victoria Magariños.
} 


\section{Resumen}

Los territorios rurales de Mendoza, particularmente los de Valle de Uco, se han visto afectados por fuertes transformaciones asociadas a dos factores clave: la acción (des)reguladora del uso del agua efectuada por el Estado y la fuerte avanzada de la expansión capitalista, vinculada a la producción vitivinícola y al turismo. Estos procesos fueron desarrollados sobre antiguos territorios ganaderos, luego fruti-hortícolas, en los que la producción de alimentos se lleva a cabo en un "paisaje natural" de indudable belleza, icónico para Mendoza. A la luz de la noción de extractivismo, el trabajo analiza "enclaves de paisajes mercancía" asociados al enoturismo de alta gama. Para ello busca responder en qué medida este tipo de turismo requiere de la configuración de enclaves de paisajes estilizados fuertemente estetizados que permitan la mercantilización de experiencias singulares. Las hipótesis de partida sugieren que: 1- la construcción de enclaves turísticos mercantiliza el paisaje para argumentar la singularidad de la experiencia turística; 2- la construcción de esos enclaves se sustenta sobre la extracción de bienes comunes y de construcción colectiva. Para proceder en esta dirección se identifica las dimensiones clave del extractivismo y se analiza las particularidades que asume en el campo del turismo. Se recurre al análisis de un estudio de caso, Valle de Uco (Mendoza), que se aborda mediante técnicas cuanti y cualitativas. Los resultados permiten comprender y profundizar dimensiones significativas de un fenómeno claramente extractivo que se activa bajo la seducción del lujo de los paisajes y que cumple la paradoja de ser a la vez, brutal y bello.

Palabras Clave: Palabras clave: paisaje; enclave; turismo; mercancía; extractivismo; vino

\section{The landscape of extractivism: the case of high-end tourism}

Extractivism in Latin America has managed to stand the test of time through its nuances and adaptations. Large-scale resource exploitation emerged as "a type of vertical dynamics that charges into territories, dismantling regional economies; destroying biodiversity; dangerously strengthening the process of land occupation by expelling or displacing rural, farmer or aboriginal communities; and violating citizens' decisionmaking processes" (Svampa 2013: 34). This is an economic development model that is based, in most cases across the continent, on the export of raw materials and low-processed items, subject to the peripheral or semiperipheral situation of each country (Wallerstein 2006). In a capitalist mode of production, extractivism reorganizes society and territory, accelerates the commoditization of nature and culture, expels rural populations, gentrifies spaces, constructs and deconstructs cultural heritage, erodes public institutions and promotes private entities as advocates of globalization.

Although the literature on extractivism occasionally refers to luxury tourism as a practice that is also extractivist in some of its dimensions, few studies analyze the relationship in depth. Some authors explore the social and territorial impacts and the extraction of value associated with the enclave-like modality of luxury tourism (Brenner and Aguilar 2002; Carlisle and Jones 2012; Craviotti 2007). Others address the resulting deterioration of democracy given its dominance by large international companies (Buades 2010), while some focus on gentrification and the amenity migration processes that occur as a result in urban and rural areas (Blázquez, Cañada and Murray 2011; Hiernaux and González 2014; Nelson and Nelson 2010; Rainer and Malizia 2014). Finally, some authors elaborate on the consequences in local contexts of the processes of conversion to heritage status and the commoditization of traditional practices (Frigolé 2018). Although all authors address dynamics that may be linked with extractivism, such as large transfers of capital between sending and receiving destinations, and environmental impacts, the concept is not addressed in this literature.

A different literature is devoted to the study of business in connection with luxury, and the ongoing reestablishment and renewal of the constituent variables of its products, including tourism (Atwal and Williams 2009; Fernández Galhanone, Marques, Toledo and Mazzon 2010). Some of these authors are agencies and consultants that are monitoring the market after having implemented strategies to satisfy and/or create new demand in a highly mobile segment of business (D'Arpizio et al. 2015). Studies explore the market niche for business management and control from a strictly economic perspective, in order to learn about the profile of demand, consumer characteristics, localizations and other meaningful features of luxury product sales. These works do not pose the behavior of the rich, or luxury product placement, as extractive. Thus, while there is scientific literature on extractivism, and also on tourism, the luxury tourism-extractivism-enclave nexus has barely been studied (but see Torres et al. 2018). The scope of available research becomes even narrower when adding the commoditization of landscapes as a result of tourist flows into the equation. This article addresses 
these issues through a study of Mendoza, Argentina, where luxury tourism is promoted through the constitution of landscape enclaves.

\section{The landscape}

Landscape has always been studied using multiple approaches, both in the world of art as well as in a variety of disciplines and aesthetic expressions, particularly in recent years (Pastor et al. 2016). Currently, the conceptual framework behind this notion is diverse, ranging from an orthodox aesthetic-centered idea of landscape design to the most qualitative interpretations focused on social representations and imaginaries (Silvestri and Aliata 2001). This disparity between theoretical approaches and empirical references posits serious challenges in terms of the use of 'landscape' for knowledge production (Pinto Correia and Kristensen 2013). Paradoxically, this is where landscape becomes opaque and elusive to the point of rendering any dimension beyond "natural beauty" (Raffa and Pastor 2012; Silvestri 1999) invisible (Lindón 2007; Nel-lo 2007).

Milton Santos (1996: 62) offers some useful definitions of landscape that can serve as a starting point. He claims landscapes respond to two classifications: natural and artificial. Artificial landscapes result from the use of nature for political, technical or other reasons. Additionally, Santos states that the landscape is always heterogeneous and that it will not last forever since it is the result of "successive additions to and subtractions from historical heritages that are representative of a variety of ways to produce things." For this reason he maintains that "the more complex social life is, the more distanced we get from what is natural and the stronger we head toward the artificial" (Santos 1996: 62-65).

In light of these considerations, Urquijo and Barrera (2009) argue for using a "monistic epistemic approach" that interprets the landscape within a framework of oneness that integrates nature and society without dividing the components. Their stance includes human beings not only in ecological processes, but also in other dimensions, such as aesthetics. From this perspective, the landscape is defined as "the spatial-temporal unit where the elements of nature and culture coalesce into a solid yet unstable communion" (Urquijo and Barrera 2009: 231-232). Nogué (2007) adheres to this approach by claiming landscape is a social construction, as does Mitchell (2007) when he depicts landscapes as systems that articulate social reproduction, and he breaks down the myth of purely "local" landscapes.

Some authors build on the idea that landscapes are socially constructed to argue that they are a common good (Petroncelli 2014; Mattiucci and Staniscia 2014; Scoppetta 2014). Laura Menatti (2014) points out that if landscape is a common good, this means it is a public and social good reflecting shared environmental and political values, and should be understood normatively as preserved through the assertion of human rights. She emphasizes that this view stresses ethical values and not only aesthetic ones, characterizing the landscape as a good that is intended not only for pleasing the eye but also for living. Along similar lines, some authors have explored how the landscape is shaped by commoditization processes. Villar Lama (2013) points out that landscapes cannot be simply regarded as passive recipients of tourism-related impacts. On the contrary, featuring them as a visual product enhances their value as real estate. But the commoditization of landscapes involves a paradox: while landscapes will attract capital investments, these valuation process will very often result in the degradation and trivialization of the previously valued element - the landscape itself, as investments grow in scale and alteration advances, changing landscape 'character.'

\section{Tourism}

Since tourism involves a variety of territories and forms of territoriality, its analysis requires a variety of scales and perspectives. The extractivist logic absorbs tourism and articulates it by reconfiguring the activity and the territories where it occurs as a driving force for the constitution of imaginaries that legitimate the neocolonial process. This perspective shows the territorial idealization of Latin America as a tourist site with important historical background, most evident in Latin American eldoradismo, which refers to the legend of El Dorado and the ongoing quest for riches in the New World (Svampa 2012). This is particularly important because it directs attention to conceptual mechanisms that legitimize the connection between development and extractivism. Latin America's image as a blossoming garden has existed for centuries. It was depicted as such 
by the conquistadores in their quest for the mythical city of El Dorado, and served as the muse which inspired Thomas More's Utopia. The ideological construction of the territory has become a common tool: the opulence connected with El Dorado welcomes limitless exploitation even as it hides killing and destruction and conceals the shifting frontier subjected to appropriation. In other words, tourism may be leading to territorial transformations that are in line with classic extraction practices such as those deriving from hydrocarbons, mining and infrastructure (Svampa 2013). It is also the case that luxury tourism is associated with social elites (Bertoncello 2006; Judd 2003), because the wealthy have resources not so available to other social groups: leisure time and the means to travel. Luxury tourism ventures away from the idea that their businesses are a vector for "development", especially rural development. The promotion of elite tourism has instead resulted in the phenomenon of tourism enclaves, discussed below.

Moreover, luxury tourism constitutes an export activity involving in situ consumption of raw materials that generates a dual condition. On the one hand, it offers clients a seemingly non-transformed nature and, on the other, the customized production of a cultural landscape suited to the demands of elite consumers or the commodities that the destination "brand" wishes to sell. The combination of nature and design enhances the status and appreciation of the landscape as a commodity in the tourism market, a process seen by Mosedale (2016) as the neo-liberalization of tourism.

\section{Wine capitalism}

Attention to the dynamics of capitalism enables the exploration of the production processes behind commodity landscapes in the wine region of Mendoza, Argentina, and more specifically, in the Uco Valley. Yelvington's work (2012, 2014) provides a treatment of both landscape and tourism within a framework of "wine capitalism." He discusses the development policies applied in the Temecula Valley, in southern California, to promote wine tourism and real estate operations. The winemaking industry aims at "territory branding" by boosting the concept of terroir, which is deeply rooted in notions of nature and rural authenticity. In an attempt to promote the development of the Temecula Valley as a winemaking region, the wine sector foregrounded its particular interests, much to the detriment of environmental sustainability and the interests of other participating social actors. The process of commoditization of terroir blends the elements in the area into oblivion in an attempt to craft a brand (Yelvington 2012). In Temecula this process has fostered an increase in the number of wineries and related businesses (wine clubs, tasting rooms, wine stores, etc.), which in turn has aggravated local groundwater scarcity. Yelvington uses Lefebvre (2013) to analyze the production of space in a place whose "authenticity" resides in the peace and quiet of unoccupied rural areas.

Don Mitchell adds two more axioms useful for the interpretation of landscape as a commodity. Axiom 1 states that "the landscape is produced" (Mitchell 2008: 34) and calls for an analysis of the relationships and networks underpinning this production. Understood as a process defined by capitalism, "landscape production is commodity production" (Mitchell 2008: 34). The author goes even further in Axiom 2, stating that in capitalism "any landscape is (or was) functional" and, therefore, "all landscape is speculative: it is a banking of capitalist value [...] creating the conditions for the realization of even more capitalist value" (Mitchell 2008: 35). Although this statement may be challenged when applied to other contexts, it offers an accurate account of the design of landscape production resulting from wine capitalism. In keeping with this perspective, then, it may be inferred that exchange value is inherent to landscape production. As a produced item, the landscape acquires the status of a commodity for consumption (Beilin 2001; Santamarina 2009; Villar Lama 2013). This type of commodity therefore requires capital flows for a two-fold purpose: 1) establishing a production site, and 2) building new networks on which to establish a tourism market connected with winemaking and real estate sales.

\section{Materials and methods}

This article discusses extractivism and enclaves of commodity landscapes located in the heart of the Uco Valley, a region in Mendoza undergoing accelerated processes of capital expansion associated with winemaking production and high-end tourism. Out of around 26 high-end wine tourism ventures in the Uco Valley, this article analyzes seven, which are to be to be taken as study cases (Neiman and Quaranta 2006). Two significant 
characteristics co-occur in all seven ventures: 1) they bring together wine production and high-end wine tourism and 2) they can be defined as enclaves.

The article presents a description of the main characteristics of the wine-tourism ventures, based mostly on semi-structured and in-depth interviews, together with the document analysis technique (Valles 2000). Additionally, the article discusses the claims made by owners and senior staff when placing their products for "viewing and selling." The main goal is to analyze the venture landscapes as part of the tourism products they promote. This analysis takes into account what the ventures say about the landscapes, what characteristics and values are appraised, and what narratives are used to make them visible to potential consumers. It should be noted that this article does not intend to analyze how these contents are received by their target audience or how the experience offered by the enclaves is perceived by tourists.

Twenty-five semi-structured interviews were conducted between August 2015 and January 2017, targeting people connected with the local and provincial tourism scene. Additionally, seven in-depth interviews were conducted with the owners or senior staff members of the ventures, and these were complemented by a series of field observations of the ventures and by applied document analysis of the narratives offered by the ventures on their websites. Categories of analysis were developed to refer to the way in which the ventures describe themselves, how they communicate their landscape production process, what experiences they offer, the extent to which they establish relationships with the territory and the manner in which they do so.

\section{Global processes with a local expression in luxury enclaves in the Uco Valley}

Mendoza has been part of Argentina's tourism sector since the activity began in the country. Initially prompted by balneotherapy ${ }^{2}$, to be followed by snow-related activities and wine, Mendoza has constantly broadened its services as a tourist destination, readjusting and expanding its tourist areas. Public policies, especially as from the early $21^{\text {st }}$ century, gave a major boost to tourism. These policies, combined with the economic restructuring process at the time, found wine tourism to be a perfect blend that fostered the development of both sectors. The vineyards-tourism association favored a progressive intensification of that activity in the territory, created new tourism enclaves and encouraged the establishment of transnational companies.

As may be read on the website of the Investment Promotion Agency of Mendoza ${ }^{3}$, the province "is one of the world's top 50 travel destinations and stands among the top three in South America. It is also one of the ten Great Capitals of Wine", and its Harvest Festival has been chosen as the second most important harvest event in the world. In addition to these statements, the website expands on a number of reasons to choose Mendoza as a solid investment opportunity in tourism. It mentions the "stunningly beautiful landscapes" and the "wide range of options: wine tourism, rural tourism, conventional tourism, extreme sports and tourism, MICE [meetings, incentives, conferences, events] tourism, and medical tourism." This convergence of factors, intentions and decisions are expressed in the territorial transformation that has taken place in the Uco Valley. These factors currently remain as strong elements of persuasion for tourists, especially foreign ones.

Located 70km from the capital city in the mid-west of Mendoza, the Uco Valley is a haven for irrigated agriculture. The valley lies between the frontal side of the Andes mountain range and the region of Huayquerías, at an altitude between 900 and 1,200 meters above sea level. Formed by the districts of San Carlos, Tunuyán and Tupungato, the valley extends across approximately $17,370 \mathrm{~km}^{2}$. In 2010, the Uco Valley had a population of 114,613 inhabitants, 57.8\% of whom lived in the urban area and $42.2 \%$ rural (National Institute of Statistics and Census of Argentina, INDEC 2010). The cities in the area serve a vast region also known as the Central Oasis (Figure 1).

According to archaeological evidence, the Uco Valley had a long history of land occupation by different Indigenous groups during the Pre-Hispanic era (Bárcena and Ots 2012). Spaniards began their settlement in the late 16th century and promoted livestock ranching in the area. The Society of Jesus, established in the area in

2 Bathing in mineral waters.

3 Investment Promotion Agency of the Province of Mendoza (Mendoza Invest). [Accessed March 15 2019] http://invest.mendoza.gov.ar/?page_id=2826 
1622, would continue this activity into modern times (Bárcena and Ots 2012; Torres et al. 2018). In colonial times, the Uco Valley had already acquired strategic value in the regional economic sphere. This was due not only to its proximity to mountain passes that cross the Andes mountains and provide access to the Pacific Ocean (Cirvini 2012), but also to the beneficial tax conditions that were in effect for transporting goods across the Andes (Ots, Cahiza and Gascón 2015). Over the course of the 20 $0^{\text {th }}$ century, the most prominent production activities in the Uco Valley were those connected to wine growing, some fruit production and horticulture, as well as the by-then traditional livestock activities (Lacoste 1996).

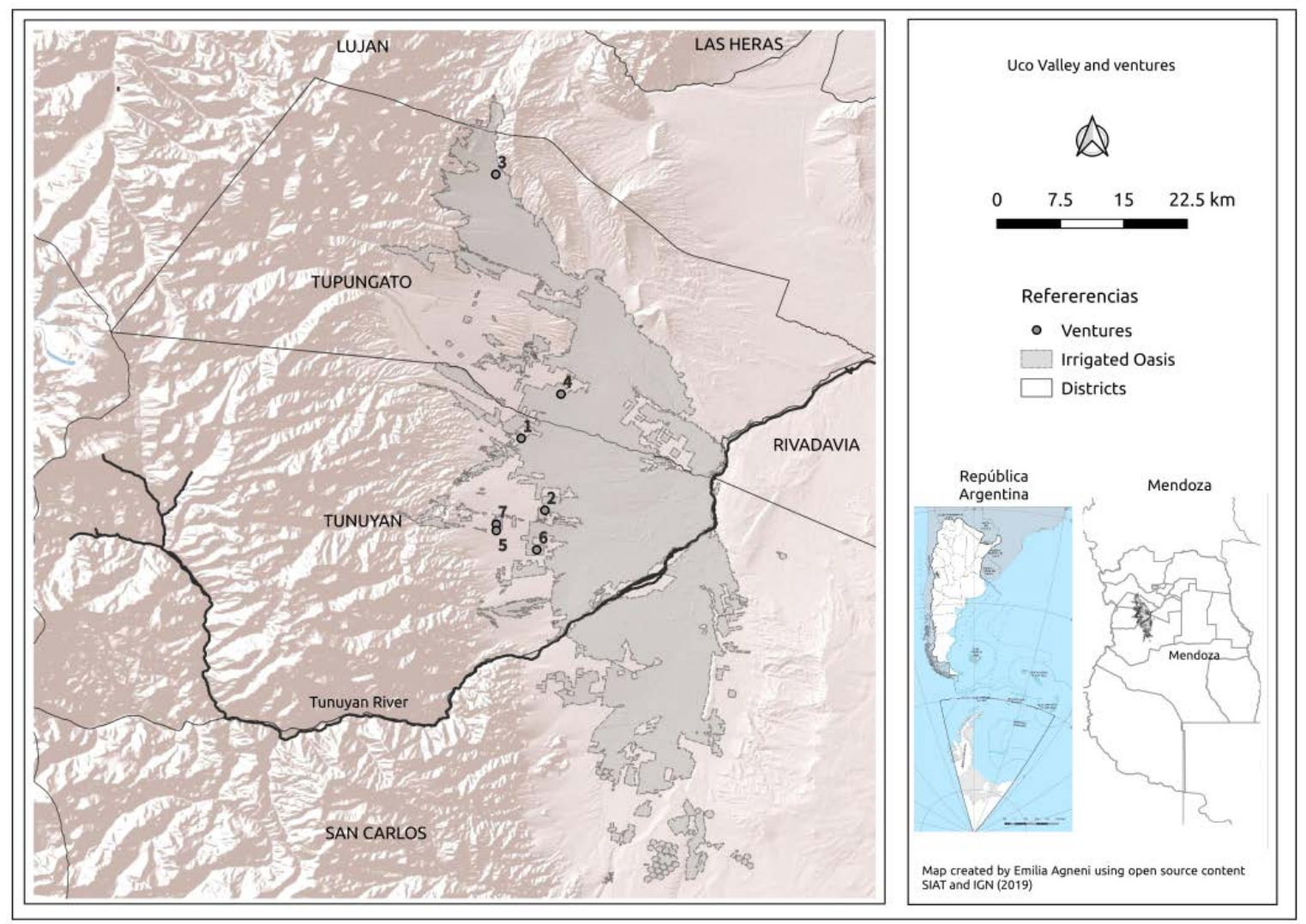

Figure 1: Map of the Uco Valley.

This scenario changed drastically at the end of the $20^{\text {th }}$ century and beginning of the $21^{\text {st }}$, when the province's wine industry, particularly in the Uco Valley, was restructured. Driven by domestic and foreign conditions, Mendoza winemaking moved from a production paradigm based around the "quantity/domestic market" equation, to a new one seeking to supply "quality/foreign markets." The deep transformations that ensued in production and organization involved introducing selected varieties with the aid of grapevine genetics as well as modern growing and irrigation techniques. The sector shifted its orientation toward premium wine production targeted at markets worldwide, which resulted in a renewal of the products for sale, and the creation of a more refined image that was appealing to new consumers. A key element of this transformation was the cultural construction of terroir for the new wines, which blended the traditional and the modern, the local and the global, the native and the foreign, ultimately lending evidently hybrid products a halo of design (Yelvington 2011).

The restructuring of the wine industry contributed to the development of rural tourism. Along with the areas located to the north and south, the Uco Valley boasts impressive natural and cultural attractions that provide plenty of wine tourism activities. Unable to compete with more mature and established destinations 
(Napa Valley, Bordeaux, and La Rioja, among others), the Uco Valley set to build a brand of its own that combined its natural winegrowing conditions with its natural and cultural landscapes. In the present day, the Uco Valley features 72 wineries, 26 of which are open to tourism and offer a growing but well-defined portfolio of products, aimed at satisfying leisure and recreational demands from an affluent foreign public. Outside the winemaking sphere, rural tourism involving traditional farming estates and ranch outposts was also given a major boost. In this case, added value was allotted to that part of the history of Mendoza linking the Uco Valley to General José de San Martín's campaign of national independence and the ancient estates that regulated the flow of livestock across the mountain passes on their way to Chile.

Argentina's wine routes, an itinerant tourism program around which all tourism products from the Uco Valley are coordinated, comprise a broader proposal "around a storyline related to local or regional heritage" (Girini 2005: 2). The Uco Valley has now consolidated its productive profile around agriculture and has become one of the main wine tourism destinations worldwide (INV 2016). Productive activity and the job market have been rearranged by newly established vineyards, the establishment of foreign companies interested in relocation and foreign investment, and infrastructure development. In order to articulate, promote and sell wine tourism products in relation with wine production, the ventures in Mendoza's luxury sector resort to a set of images that resemble a dreamlike postcard. Thus, wine capitalism produces not only its space, but also its representations (Lefebvre 2013). Localized "nature" is presented-represented by means of a visually anchored strategy: the view of vineyards and the mountain range (Figure 2).
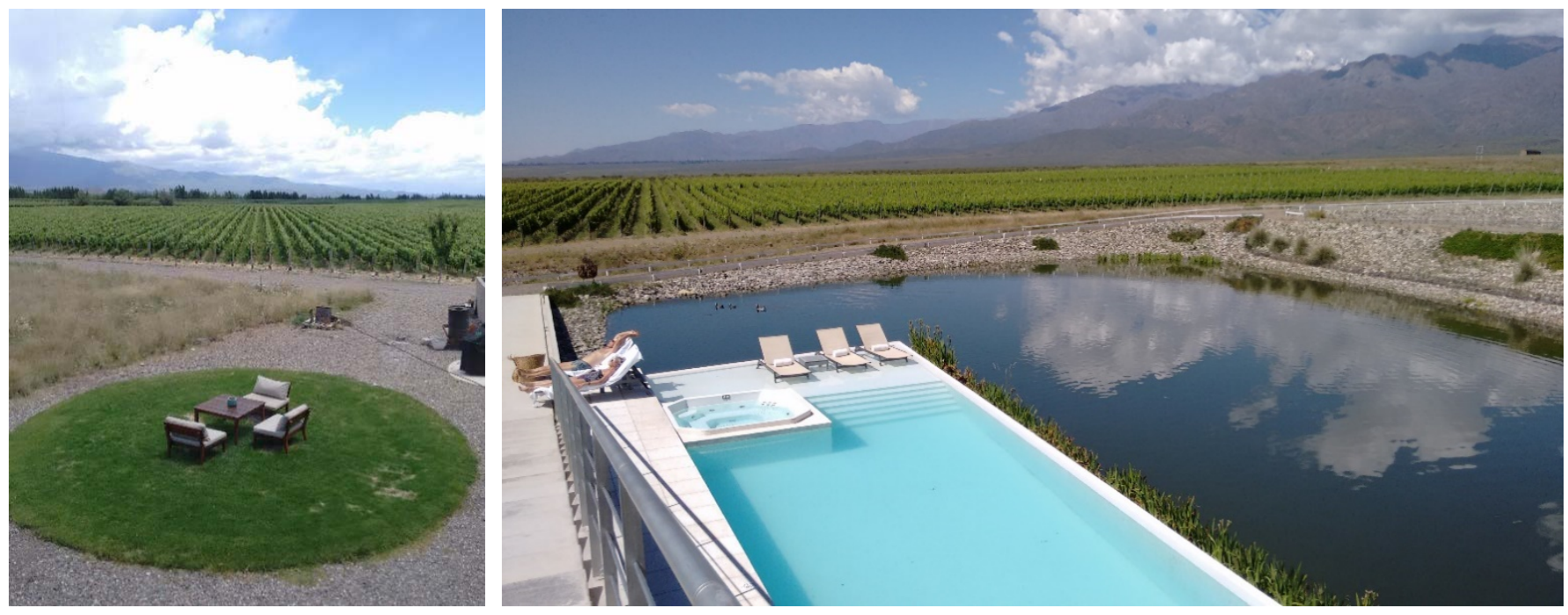

Figure 2: Wine resorts at Tunuyán, Uco Valley. Source: authors.

Wine tourism enclaves

The enclave is often seen as a product of "outward development", where the exporting sector that is "enclaved" in the world periphery establishes a direct extension of the economy developed in the core regions (Fogel and Riquelme 2005). Cammarata (2006: 363) describes these structures as deterritorialized sites establishing "weak relations and economic and social articulations in the territory, which derive from exogenous growth factors that are fostered at the provincial and national level." Jameson (2005) and Roberts (2009) argue that an enclave is also a space where new images and desires may be created and experienced from a social perspective. They are "nodes of foreign circuits of capital and culture that are colonizing and replacing the local sites" (Judd 2003: 52). Focusing on cultural analysis, Zukin (1991) and Carlisle and Jones (2012) argue that the enclave is a dream landscape that promotes fantasy and eclipses reality. A tourism enclave ultimately renders the experience of a closed space and society that is available only to a few and creates "an environment overpowering their senses with the signs and symbols of consumption and play" (Judd 2003: 55). According to 
this perspective, tourism enclaves are mainly designed to manage tourists' desires, schedules, consumption habits and flows. High-end tourist enclaves in Mendoza and throughout Latin America region exhibit these characteristics (Blázquez, Cañada and Murray 2011; Larsimont 2017).

The wine-capitalism tourism ventures treated in this article are high-end vineyards and wineries, featuring limited accommodation capacity, spas, and recreational and sports amenities in enclosed spaces that have been reinforced and markedly separated from local territories (Table 1). As revealed by the data obtained in the field, these are relatively new projects owned by extra-territorial capital. In some cases, they are the result of the association of domestic and foreign capital, while other projects are owned by foreign capital alone.

The seven ventures studied here show heavy dependence on global forces that channel investment through hierarchical financial currents and govern the forms of interaction with the wider landscape and territory of the Uco Valley. These forms of interaction are largely restricted to the grounds of the established projects, and in setting the boundary for interactions, the organization of leisure activities inside the enclaves play a key role, but design also contributes to their execution. Indeed, these ventures manage tourists' schedules, movement patterns and consumption habits, and they appear as enclosed, protected areas against an outer world deemed as threatening. "Nature" is presented as both untamed, when it is outside the borders established by the enclave, and tamed, when it occurs within enclave boundaries (Lefebvre 2013).

Socialization is kept within enclave walls and interactions with the outside are restricted to specific, strategic and synergistic articulations with other wine tourism ventures displaying similar characteristics. As the following claim reveals, most of the ventures promote themselves as offering experiences such as recreational activities or strolls within the destination enclaves. When broaching the enclave borders, tourists are invited to visit similar ventures, which are often located in the same region and connected logistically by the issuing venture:

The hotel is trying very hard to actively sell its services so as to get the rooms booked. These people are offered horseback rides across the vineyards, trekking, biking, the gym... There's a restaurant offering breakfast, lunch, dinner, as well as cooking classes. The hotel features a spaand it's all inside the company. The experience proves highly positive for tourists. Guests will typically come and start consuming [the product] from day one: they'll get here, have breakfast, have lunch, take a tour of the winery, then do some horseback riding, then have dinner... The following day, we might set up a tour outside the premises of the project, in another winery. Overall, the wineries in the area have a good relationship with one another. We all make wine, but no one makes exactly the same one... (Interview excerpt, Case 2)

Attracted by the potential for investment and employment, state participation is highly biased toward serving the needs of private actors. As expressed by government officials, in the context "'this nature-friendly' industry, the private sector acts as the true driving force; the national state should provide logistics support and infrastructure" (Interview excerpt). This is a trend in leisure governance (Yelvington 2012), where the national state implements a neo-liberal cycle of deregulation and re-regulation, tailored to the needs of the actors who have appropriated the spaces (Mosedale 2016). The state develops the regulating frameworks and looks for cracks in the system that can be exploited to create the set of conditions required by capital. In return, the state is guaranteed its participation in the new uses assigned to the appropriated public goods (Gudynas 2009). The state presents itself as a "lady-in-waiting to capital", a role that is coherent with neo-extractivism.

The enclave-like modality typical of these ventures also drives a set of imaginaries reminiscent of Latin American eldoradismo, which redefine the landscape appropriated by capital. As the following interview excerpt states, the ventures resort to an aesthetic proposal that is rooted in the ideas of terroir and "authenticity", but that has been simplified by the filter of globalization and the ever-present need to have consumers decode the destination as part of the world's wine landscapes:

... We offer rounds of mate, then tourists can learn how to cook some of our regional dishes... This is something much more rural, it's not your average gourmet meal. American tourists, those 
who come from abroad, love this, especially the taste. They're attracted to the whole presentation; they love that show. It's where you can showcase everything, and we can amplify their experience-we can make them feel free and comfortable doing this. At night, there's Wi-Fi and hot water... (Interview excerpt, Case 5)

\begin{tabular}{|c|c|c|c|c|c|c|c|}
\hline & Case $1^{4}$ & Case 2 & Case 3 & Case 4 & Case 5 & Case 6 & Case 7 \\
\hline $\begin{array}{l}\text { Start-up } \\
\text { of } \\
\text { operation } \\
\text { s in the } \\
\text { Uco } \\
\text { Valley } \\
\end{array}$ & 1999 & 2005 & 2006 & 2008 & 2008 & 2009 & 2011 \\
\hline $\begin{array}{l}\text { Size of by } \\
\text { venture }\end{array}$ & 2,000 ha & $\begin{array}{l}250 \text { ha } \\
\text { initially; } \\
670 \text { ha } \\
\text { currently }\end{array}$ & $\begin{array}{l}700 \text { ha } \\
\text { initially; } \\
1,000 \text { ha } \\
\text { currently }\end{array}$ & 840 ha & 325 ha & 404 ha & 85 ha \\
\hline $\begin{array}{l}\text { Origin of } \\
\text { capital } \\
\text { and } \\
\text { previous } \\
\text { activities }\end{array}$ & $\begin{array}{l}\text { Dutch } \\
\text { capital with } \\
\text { experience } \\
\text { in } \\
\text { vineyards, } \\
\text { agriculture, } \\
\text { farming and } \\
\text { hospitality. }\end{array}$ & $\begin{array}{l}\text { Mixed capital } \\
\text { (Argentine- } \\
\text { American). } \\
\text { Businesspeopl } \\
\text { e in wine trade }\end{array}$ & $\begin{array}{l}\text { French } \\
\text { capital with } \\
\text { experience } \\
\text { in } \\
\text { international } \\
\text { hospitality }\end{array}$ & $\begin{array}{l}\text { Belgian } \\
\text { capital, } \\
\text { then sold to } \\
\text { Spanish } \\
\text { investors }\end{array}$ & $\begin{array}{l}\text { Domestic } \\
\text { capital } \\
\text { (Buenos } \\
\text { Aires) } \\
\text { initially } \\
\text { linked to } \\
\text { construction } \\
\text { and real } \\
\text { estate }\end{array}$ & $\begin{array}{l}\text { Domestic } \\
\text { capital } \\
\text { (Buenos } \\
\text { Aires) with } \\
\text { experience } \\
\text { in forestry, } \\
\text { vineyards } \\
\text { and } \\
\text { construction }\end{array}$ & $\begin{array}{l}\text { Foreign } \\
\text { investment } \\
\text { pool; } \\
\text { "wine } \\
\text { lovers" } \\
\text { from all } \\
\text { over the } \\
\text { world }\end{array}$ \\
\hline $\begin{array}{l}\text { Main } \\
\text { activity in } \\
\text { the Uco } \\
\text { Valley }\end{array}$ & $\begin{array}{l}\text { Vines and } \\
\text { wines }\end{array}$ & $\begin{array}{l}\text { Vines and } \\
\text { wines }\end{array}$ & $\begin{array}{l}\text { Vines and } \\
\text { wines, } \\
\text { fruit trees, } \\
\text { livestock }\end{array}$ & $\begin{array}{l}\text { Biodynamic } \\
\text { vineyards }\end{array}$ & $\begin{array}{l}\text { Vines and } \\
\text { wines, } \\
\text { organic } \\
\text { orchards }\end{array}$ & $\begin{array}{l}\text { Vines and } \\
\text { wines }\end{array}$ & $\begin{array}{l}\text { Vines and } \\
\text { wines, } \\
\text { organic } \\
\text { orchards }\end{array}$ \\
\hline $\begin{array}{l}\text { Start-up } \\
\text { dates }\end{array}$ & 2001 & $\begin{array}{l}\text { 2006, heavily } \\
\text { consolidated in } \\
2013\end{array}$ & 2012 & $\begin{array}{l}2008, \\
\text { relaunched } \\
\text { in } 2017\end{array}$ & 2008 & 2009 & 2011 \\
\hline $\begin{array}{l}\text { Tourism } \\
\text { offerings }\end{array}$ & $\begin{array}{l}\text { Boutique } \\
\text { Lodge, } 16 \\
\text { rooms }\end{array}$ & $\begin{array}{l}\text { Resort and spa, } \\
22 \text { rooms }\end{array}$ & 6 Lodges & $\begin{array}{l}\text { Hotel and } \\
\text { spa, } 16 \\
\text { rooms }\end{array}$ & $\begin{array}{l}\text { Resort, } 16 \\
\text { rooms }\end{array}$ & $\begin{array}{l}\text { Boutique } \\
\text { Guesthouse, } \\
14 \text { rooms }\end{array}$ & $\begin{array}{l}\text { Inn, } 5 \\
\text { rooms }\end{array}$ \\
\hline & $\begin{array}{l}2 \\
\text { Restaurants, } \\
\text { Art Gallery, } \\
\text { Business } \\
\text { center, } \\
\text { Chapel } \\
\end{array}$ & Restaurant & $\begin{array}{l}\text { Restaurant, } \\
\text { Golf course } \\
\text { (9 holes), } \\
\text { Fish } \\
\text { farming }\end{array}$ & $\begin{array}{l}\text { Restaurant, } \\
\text { Golf course } \\
\text { and club } \\
\text { (18 holes), } \\
2 \text { polo } \\
\text { fields }\end{array}$ & Restaurant & $\begin{array}{l}\text { Guesthouse, } \\
\text { Clubhouse } \\
\text { with } \\
\text { swimming } \\
\text { pool and } \\
\text { BBQ grill }\end{array}$ & Restaurant \\
\hline $\begin{array}{l}\text { Real } \\
\text { estate } \\
\text { product }\end{array}$ & $\begin{array}{l}\text { Undisclosed } \\
\text { information }\end{array}$ & \multicolumn{6}{|c|}{$\begin{array}{l}\text { With a few nuances among them, the real estate consists of estates with their own vineyards } \\
\text { and an area to build a house (between } 0.5 \text { and } 5 \text { ha) and smaller parcels (between } 1,000 \text { and } \\
3,000 \mathrm{~m}^{2} \text { ) for housing construction with access to the common vineyards. In every case, the } \\
\text { projects are located in a larger property featuring common areas and services (wineries, } \\
\text { restaurants and hotels, among others) that is responsible for their management and } \\
\text { maintenance. Case } 3 \text { presents a variation, since the private parcels are devoted to livestock } \\
\text { production and equestrian activities. }\end{array}$} \\
\hline $\begin{array}{l}\text { Real } \\
\text { estate } \\
\text { prices }\end{array}$ & & \multicolumn{6}{|c|}{$\begin{array}{l}\text { Presenting wide variations depending on the areas and the characteristics of each venture, } \\
\text { and with many information gaps, the prices range from US } \$ 100,000 / \text { ha to US\$ } 120,000 / \text { ha. }\end{array}$} \\
\hline
\end{tabular}

Figure 2: Table comparing aspects of 7 wine tourism businesses in the Uco Valley. Prepared by the authors on the basis of the field survey.

\footnotetext{
${ }^{4}$ The names of the ventures have been omitted to ensure confidentiality.
} 
In that "show", sanitized copies of vernacular architecture emulate a sophisticated ruggedness that contributes to the validation of the experience. A globalizing "validation" of the local, it leads to the substitution of places: the simplification of a landscape that is homogeneously covered in vineyards and extends along the mountainous horizon line (a highlighted aspect of Mendoza's territorial identity) is attached to a limited storyline starting with the enclave activity. This storyline is given its own coherent narrative and is separated from the actual condition of the system, i.e. the system being dismantled. Sanitization operates on the aesthetic level, but does not remain neutral in terms of the construction of the space itself, because the role of work and workers is made invisible. The social dynamics of space and its production are lost and landscapes become fetishes, much like in the case of commodities (Lefebvre 2013).

Historical landscapes that are lived areas for a number of social groups remain frozen as postcard images and, as objects of tourist consumption, increasingly lose their original uses and functions. The process of restructuring historical landscapes entails abandoning and replacing the existing socio-productive fabric with a fictional story that ultimately renders a unified, conflict-free landscape. In order to achieve this, the enclave installs structures and security devices that promote a strong rural gentrification process that eradicates existing social fabrics and makes the ground fertile for the reproduction of Latin American eldoradismo. This romantic attitude is produced through activities in which the surroundings are limited to a postcard image whose aesthetic value is assigned by the worldview shared by the businessperson and the tourist. In this land of make-believe, tourists "play" at harvesting the vineyards.

\section{Perceptions of the landscape enclave}

The construction of landscapes as commodities depends on the subjective and perceptive arrangement that the vineyards, tourism and real estate businesses use to insert themselves in the territory. Emerging from the analysis of our interviews and the claims of the tourism businesses advertised on their websites, at least five main themes become evident in the description of their own landscape perceptions, with various degrees of explicitness or nuance. One invariable theme consists in giving renewed value to the foundational character behind the new landscape. Although the innovative character of the projects is highlighted in all cases, this is also done with subtle differences: either by associating the production of a new landscape with a Latin American character improved by European influence or by relying on the excellence of American business practices. A different case takes up some of the meanings behind the idea of "tradition", especially in terms of the use of certain building materials and techniques.

Along these lines, the information available on the website for Case 1 describes how that venture transformed a desert into the fertile oasis that is now typical of Mendoza. The website even points out that the winery, located in the Uco Valley, harmonically coalesces with both nature and culture in the site. As for construction materials, Case 1 expresses its respect for the land and customs, evident in its use of natural materials as an homage to the Andean cultural roots of the area. Similarly, Case 3 conveys the spirit of the land in its use of rock. The circle of aestheticizing virtuosity can be summarized in the words taken from Case 6 and Case 2. In Case 6, claims are made about having crafted the ultimate pairing between Latin America's colors and Europe's sophistication. Case 2, for its part, boasts about its perfect combination of rugged elegance and modern comfort.

Furthermore, this foundational character appears attached to the level of sophistication offered by the tourism product. This is an aspect deliberately pointed out by the ventures that showcase the exotic quality of the foreign element as a new value added to the territory. One of the cases highlights the transformation processes in the region, Argentine viticulture and wine tourism, linking it to the foundation of the winery (Case 1). Another one prides itself on epitomizing truly emotional luxury and representing a historical milestone among real estate projects, while claiming to have sealed an everlasting commitment to its roots in the area, its protection of natural resources, and its utmost respect for the landscape (Case 5).

Strikingly, however, the foundational character of the winery is associated with the idea that the area was a void in past times. This idea of nothingness prior to the enclave is meaningful, as one of the interviewees from the management points out in Case 2: "Before... nothing... just weeds, rocks, a few foxes... this was a wild, non-cultivated plot" (Interview excerpt, Case 2). When the idea of a vacuum is disproved after further 
questioning about farming in the area, the discourse about "nothingness" morphs into "discrediting narratives", a paraphrased denial of the previous presence in the site, now described as a fallow land:

You'll find stables for horse grazing in the area... also goats, but nothing that really strikes you as 'wow, this is major production'. Many times you'll see fields covered in weeds and a few horses and you'll say 'oh, so there's horses', because these were fallow lands. (Interview excerpt, Case 2)

As will become evident in the discourse of the ventures, authentic and traditional farmers and farming uses are precisely what constitute crucial lines of value enhancement in the products of tourism.

In these descriptions there is a bucolic interpretation of a landscape and rural life in which a pleasurable peace and quiet or an easy, unhurried pace (needed to create a good wine) are all natural and authentic elements inscribed in the terroir. The venture in Case 1 presents its site as one that is embraced by the sun and the winds that blow down the Andes; a stunning landscape where the spirit of past generations lives on. All of these elements configure a present time where the only premise is to relish the landscape, its surrounding nature, and art. Case 6 defines itself as "your place in the world", given the quiet atmosphere of its vineyards and the breathtaking view. Case 7 claims to be a place for unforgettable experiences while the site of Case 4 is where one can fully experience the ancient wine culture. Case 3, in turn, deploys the idea of a void and assigns it the new meaning of a "wild space", a twist that stands as an extreme example of commoditization. Traditional flavors and regional dishes crafted by the hands of local gauchos are exalted, with Case 3 promising to fuse the gourmet and the local (criollo), and Case 2 extending an invitation to a horseback riding on a tour led by Argentine gauchos.

Another characteristic of Uco Valley wine tourism's self-image is the altitude of the place as a tangible dimension of the landscape and tourists' experience in it. Thus, words such as "mountain range", "Andes", "sky" and "horizon" present the challenge of reaching the highest areas. Vineyards claim to be the highest in the province and among the highest in the world (Case 1) and to produce the most authentic wine (Case 5). Tourist ventures boast the highest hole in a golf course (Case 3), the best terroir with crystal-clear water (Case 6), and a luxurious, far-reaching, boundless space (Case 4). Simultaneously, however, the notion of altitude is complemented by the intangible dimension of altitude as a value, which is positioned as a marker of distinction. The exclusive, the unique, the superior, or the unprecedented become consubstantial with this perspective of distinction, which is focused on the experience within the walls of the enclave. Tourists are invited to live a unique, exclusive experience (Case 1) and a safe experience (Case 3); to enjoy an unforgettable dream and an exclusive lifestyle (Case 6); to go on a journey through high-end tradition, and to partake in the mystique behind exclusive sports (Case 4).

This is where the issue regarding the world outside the venture emerges, not because it has been explicitly considered but rather because it is ignored by the claims that such ventures make. While the space within the walls proudly boasts the value of the endless, majestic nature that generously provides water and other resources seemingly available and free from any conflict, the space outside the enclave remains anonymous. No social fabrics or landscapes are acknowledged to exist outside the intervention of wine making.

\section{Final comments}

The analysis of the cases in light of the theories developed in this article indicates that the landscape is a common good and a collective heritage, but is subject to a strong commoditization process that is part of the dynamics of 'accumulation by dispossession' (Harvey 2003) on the part of foreign capital associated with luxury tourism and wine capitalism. This leads to three questions. The first one concerns the way in which the actions entailed by this process are validated by beauty, well-being and extreme aestheticization. This validation is evident in the social imaginaries that regard Mendoza's identity as being exclusively and unquestionably anchored in the winemaking industry. The second issue involves the socio-environmental transformation that disciplines the landscape to reduce to a minimum its folds and roughness, as well as the awkward part of nature and the even more awkward "social ugliness" that transgress the borders of the enclave. In connection with the previous aspects, the third and last question involves the role taken by the nation state. While the landscape 
image depicted inside the enclaves is strongly regulated by the individual tourist-oriented ventures and vineyards in order to preserve their much-needed bucolic character, outside the boundaries of the wine-tourism ventures there is a fierce and pervasive struggle over the regulatory frameworks of the state apparatus. In consequence, the shrine-like idealization of that brutal, indomitable nature, on the one hand, and incipient rural gentrification processes, on the other, reflect two sides of winemaking-real estate-tourism development that restructures the landscape before turning to luxury enclaves and hedonism. A similar dissonance exists between the effects of extractivist activities like mining on a local landscape, and the consumption and representation of minerals as products sold on world markets.

The Uco Valley is witness to a process where luxury tourism, as a vector for the appropriation of the commodity landscape, destroys not only the monistic character behind the concept of landscape but also the integration of its object, since it isolates and creates a new hierarchy of natural and cultural components. The diverse and complex culture of territory associated with landscape appears in the simplified form of sanitized vernacular rusticity, which creates a romantic feel surrounding that sublime nature. What is understood as culture in this context is part of the "packaging" of the luxury object known as landscape. The experience of luxury, presented as a unique and exotic feature of the seductive landscape, is explained by a set of discursive, physical and symbolic mechanisms that promote the expansion of transnational capital in and across these territories.

\section{References}

Aliata, F. and G. Silvestri. 2001. El paisaje como cifra de armonía: relaciones entre cultura y naturaleza a través de la mirada paisajística. Buenos Aires: Nueva Visión.

Atwal, G. and A. Williams. 2009. Luxury brand marketing-the experience is everything! Journal of Brand Management 16(5-6): 338-346.

Bárcena, J. R. and M. J. Ots. 2012. La arboleda de Tupungato: Nota preliminar sobre el sitio fundacional hispánico del Valle de Uco, Mendoza. Comechingonia 16(1): 147-165.

Beilin, R. 2001. Underlying it all: faceless landscapes and commodified views. Rural Society 11(3): $147-161$.

Bertoncello, R. 2006. Turismo, territorio y sociedad. El 'mapa turístico de la Argentina'. In In Geraiges de Lemos, A., M. Arroyo and M. Silveira (eds.) America Latina: cidade, campo e turismo. San Pablo: Consejo Latinoamericano de Ciencias Sociales (CLACSO). Pp. 317-336.

Blázquez, M., E Cañada, and I. Murray. 2011. Búnker playasol. Conflictos derivados de la construcción de enclaves de capital transnacional turístico español en El Caribe y Centroamérica. Scripta Nova: Revista Electrónica de Geografía y Ciencias Sociales 15(368).

Brenner, L. and A.G. Aguilar. 2002. Luxury tourism and regional economic development in Mexico. The Professional Geographer 54(4): 500-520.

Buades, J. 2010. Turismo y bien común: de la irresponsabilidad corporativa a la responsabilidad comunitaria. Albasud 7: 2-31.

Cammarata, E.B. 2006. El turismo como práctica social y su papel en la apropiación y consolidación del territorio. In A.I. Geraiges de Lemos, M. Arroyo and M.L. Silveira (eds.). América Latina: cidade, campo e turismo. San Pablo: Consejo Latinoamericano de Ciencias Sociales (CLACSO). Pp. 351-366.

Carlisle, S. and E. Jones. 2012. The beach enclave: a landscape of power. Tourism Management Perspectives 1: 9-16. https://doi.org/10.1016/j.tmp.2011.12.003

Cirvini, S. A. 2012. Las órdenes religiosas en espacio urbano colonial-Mendoza (Argentina). El caso de la Compañía de Jesús. Hispania Sacra 64(130): 623-659.

Craviotti, C. 2007. Tensiones entre una ruralidad productiva y otra residencial: el caso del partido de Exaltación de la Cruz, Buenos Aires, Argentina. Economía Sociedad y Territorio 7(23): 745-772.

D'Arpizio, C., F. Levato, D. Zito, M. Kamel and J. de Montgolfier. 2016. Luxury goods worldwide market study, fall-winter 2016. As luxury resets to a new normal, strategy becomes paramount. Bain and Company. Accessed 6/6/20. 
Fernandes Galhanone, R., J.A. Marques, G.L. Toledo and J.A. Mazzon. 2010. Turismo de lujo e internet: Oportunidades para las agencias de viajes. Estudios y Perspectivas En Turismo 19(6): 888-908.

Fogel, R. and M. Riquelme. 2005. Enclave sojero, merma de soberanía y pobreza. Asunción, Paraguay: Centro de Estudios Rurales Interdisciplinarios (CERI).

Frigolé, J. 2014. Retóricas de la autenticidad en el capitalismo avanzado. Endoxa 33: 37-60.

Girini, L. 2005. Los caminos del vino en Mendoza: una propuesta metodológica para la identificación y puesta en valor. In Itinerarios y rutas culturales, vías de comunicación e intercambio de experiencias, bienes y costumbres. El patrimonio desde una mirada integral. Buenos Aries: CICOP - CNMMLH.

Gudynas, E. 2009. Diez tesis urgentes sobre el nuevo extractivismo. In Gudynas, E. Extractivismo, política y sociedad. Quito: Centro Andino de Acción Popular - CAAP Centro Latinoamericano de Ecología Social -CLAES. Pp. 187-225.

Harvey, D. 2003. The new imperialism. Oxford: Oxford University Press.

Hiernaux, D. and C.I. González. 2014. Turismo y gentrificación: pistas teóricas sobre una articulación. Revista de Geografía Norte Grande 58: 55-70.

INDEC. 2010. Censo nacional de población y vivienda.

INV. 2016. Provincia Mendoza - Área Valle de Uco - (Departamentos: San Carlos, Tunuyán y Tupungato). Departamento de Estadística y Estudios de Mercado, Subgerencia de Estadística y Asuntos Técnicos Internacionales.

Jameson, F. 2005. Archaeologies of the future: the desire called utopia and other science fictions. London: Verso.

Judd, D. 2003. El turismo urbano y la geografía de la ciudad. Revista EURE - Revista De Estudios Urbano Regionales 29(87): 51-62.

Lacoste, P. 1996. El Paso de la Cordillera de Los Andes por el Portillo Argentino. Aportes para el estudio de la integración entre Argentina y Chile. Universum 2: 101-122.

Larsimont, R. 2017. Hacía una ecología política de los negocios agroturísticos en Mendoza, Argentina. Revista Ecología Política 52: 74-77.

Lefebvre, H. 2013. La producción del espacio. Madrid: Capitán Swing.

Lindón, A. 2005. La construcción social de paisajes invisibles y del miedo. III Seminario Internacional sobre pasiatges incognits, teritoris ocults: les geografies de la invisibilitat, Barcelona.

Machado Aráoz, H. 2013. Extractivismo y "consenso social": expropiación-consumo y fabricación de subjetividades (capitalistas) en contextos neocoloniales. Revista Cuestiones de Población y Sociedad 3(3): 29-42.

Mattiucci, C. and S. Staniscia. 2014. How to deal with landscape as a common good. I Quaderni di Careggi 6(6): 34-39.

Menatti, L. 2014. Landscape as a common good: a philosophical and epistemological analysis. I Quaderni di Careggi 6(6): 40-43.

Mendoza Invest. 2016. Mendoza Invest Agency Website [accessed May $31 \quad 2019$ ]. http://invest.mendoza.gov.ar/?page_id=2826

Mitchell, D. 2007. Muerte entre la abundancia: los paisajes como sistemas de reproducción social. In J. Nogué (ed.). La construcción social del paisaje. Madrid: Biblioteca Nueva. Pp. 85-110.

Mitchell, D. 2007. New axioms for reading the landscape: paying attention to political economy and social justice. In Wescoat, J. and D. Johnston (eds.). Political economies of landscape change: places of integrative power. Dordrecht: Springer. Pp. 29-50.

Mosedale, J. 2016. Neoliberalism and the political economy of tourism: projects, discourses and practices. Farnham: Ashgate.

Neiman, G. y G. Quaranta. 2006. Los estudios de caso en la investigación sociológica. In Gialdino, I.V. (ed.). Estrategias de investigación cualitativa. Barcelona: Gedisa. Pp. 213-234. 
Nel-lo, O. 2007. La ciudad, paisaje invisible. In Nogué, J. (ed.). La Construcción social del paisaje. Madrid: Biblioteca Nueva. Pp. 183-198.

Nelson, L. and P.B. Nelson. 2011. The global rural: gentrification and linked migration in the rural USA. Progress in Human Geography 35(4): 441-459.

Nogué, J. 2007. La construcción social del paisaje. Madrid: Biblioteca Nueva.

Ots, M. J., P. Cahiza. and M. Gascón. 2015. Articulaciones del corredor trasandino meridional: El río Tunuyán en el Valle de Uco Mendoza, Argentina. Revista de Historia Americana y Argentina 50(1): 81-105.

Pastor, G., M. R. Alves, D. Sánchez Fuentes, F. Marchionni and L. Torres. 2016. Miradas e instrumentos para la catalogación de paisajes latinoamericanos. Perspectivas emergentes. Revista de Urbanismo 34: 138157.

Petroncelli, E. 2014. Landscape as a common good. I Quaderni Di Careggi 6(6): 47-51.

Pinto-Correia, T. and L. Kristensen. 2013. Linking research to practice: The landscape as the basis for integrating social and ecological perspectives of the rural. Landscape and Urban Planning 120: 248256.

Raffa, C. and G. Pastor. 2012. Representaciones, turismo y estado. Imágenes y discursos en torno de los paisajes culturales de Mendoza. Pasos 10(5): 467-476.

Rainer, G. and M. Malizia. 2014. Los countries en el country. Migración de amenidad, vino de altura y urbanizaciones cerradas en Cafayate (Salta, Argentina). Journal of Latin American Geography 13(1): 39-66.

Roberts, J. 2009. Introduction: art, 'enclave theory' and the communist imaginary. Third Text 23(4): 353-367.

Santamarina Campos, B. 2009. Cabanyal, cada vez más cerca. Del lugar al espacio como mercancía. Zainak. Cuadernos de Antropología-Etnografía 32: 915-931.

Santos, M. 1996. Metamorfosis del espacio habitado. Barcelona: Oikos-Tua.

Scoppetta, C. 2014. From "public" to "common" good. I Quaderni Di Careggi 6(6): 52-57.

Silvestri, G. 1999. Postales Argentinas. In Altamirano, C. (ed.). La Argentina en el siglo XX. Buenos Aires: Ariel. Pp. 111-135.

Stone, G.D. 2018. Agriculture as spectacle. Journal of Political Ecology 25: 656-685.

Svampa, M. 2012. Consenso de los commodities, giro ecoterritorial y pensamiento crítico en América Latina. Revista Osal 32.

Svampa, M. 2013. "Consenso de los commodities" y lenguajes de valoración en América Latina. Nueva Sociedad 244: 30-46.

Torres, L. M., G.C. Pastor, M.V. Grosso and A.E. Scoones. 2018. Turismo de lujo y extractivismo: la ruralidad como presa del capital. Reflexiones a propósito de Valle de Uco (Mendoza, Argentina). Scripta Nova: Revista Electrónica de Geografía y Ciencias Sociales 22(585): 1-32.

Urquijo Torres, P.S. and N. Barrera Bassols. 2009. Historia y paisaje: Explorando un concepto geográfico monista. Andamios 5(10): 227-252.

Villar Lama, A. 2013. La mercantilización del paisaje litoral del mediterráneo andaluz: El caso paradigmático de la Costa del Sol y los campos de golf. Revista de Estudios Regionales 96: 215-242.

Wallerstein, I. 2006. Análisis de sistema - mundo. Una introducción. Madrid: Siglo XXI.

Yelvington, K.A., L.D. Dillon-Sumner and J.L. Simms. 2014. Pleasure policies: debating development plans in southern California's Wine Country. Journal of Policy Research in Tourism, Leisure and Events 6(2): 95-118.

Yelvington, K.A., J.L. Simms and E. Murray. 2012. Wine tourism in the Temecula Valley: neoliberal development policies and their contradictions. Anthropology in Action 19(3): 49-65.

Zukin, S. 2012. Landscapes of power: from Detroit to Disney World. Berkeley: University of California Press. 